\title{
Cry1Ac-mediated resistance to tomato leaf miner (Tuta absoluta) in tomato
}

\author{
Hatice Selale $^{1} \cdot$ Fatih Dağlı $^{2} \cdot$ Nedim Mutlu $^{3} \cdot$ Sami Doğanlar $^{1} \cdot$ Anne Frary $^{1}$
}

Received: 4 April 2017 / Accepted: 2 July 2017 / Published online: 5 July 2017

(C) Springer Science+Business Media B.V. 2017

\begin{abstract}
Tomato leaf miner (Tuta absoluta) is a major pest of tomato in regions with hot climates such as South America and the Mediterranean. This insect feeds on almost every part of the plant and forms galleries while feeding on the plant's inner tissues. Thus, it can cause plant death and is costly and difficult to control with chemical sprays. In this study, we transferred a modified Bacillus thuringiensis crylAc gene to tomato plants via Agrobacterium tumefaciens mediated transformation. Introduction of the $c r y l A c$ gene to the tomato genome was confirmed with PCR and Southern blot analysis in 12 independent events. Insertion sites of the transgene in the tomato genome were determined with TAIL-PCR (thermal asymmetric interlaced polymerase chain reaction) for four selected transgenic lines. CrylAc gene expression was verified at both the transcriptional and translational levels, with RT-qPCR and Western blot analyses, respectively. Expression of the Cry1Ac protein in tomato resulted in T. absoluta mortality rates of $38-100 \%$ depending on transgenic line. In addition, gallery formation was reduced in $57-100 \%$ of
\end{abstract}

Communicated by Jose M. Segui-Simarro.

Electronic supplementary material The online version of this article (doi:10.1007/s11240-017-1262-z) contains supplementary material, which is available to authorized users.

Anne Frary

annefrary@iyte.edu.tr

1 Department of Molecular Biology and Genetics, Izmir Institute of Technology, 35430 Urla, Izmir, Turkey

2 Department of Plant Protection, Faculty of Agriculture, Akdeniz University, 07058 Antalya, Turkey

3 Department of Agricultural Biotechnology, Faculty of Agriculture, Akdeniz University, 07058 Antalya, Turkey the transgenic plants. Moreover, it was found that a single copy of the gene in the hemizygous condition is sufficient to confer tolerance to leaf miner. This is the first reported development of tomato plants resistant to $T$. absoluta. These transgenic plants are promising for development of commercial tomato cultivars resistant to leaf miner, which will limit the use of environmentally harmful chemicals for control of this pest.

Keywords Agrobacterium tumefaciens $\cdot$ Bacillus thuringiensis $\cdot \mathrm{Bt} \cdot$ Genetic transformation $\cdot$ Solanum lycopersicum . Tomato pinworm

\section{Introduction}

Tomato (Solanum lycopersicum) is one of the world's most important horticultural crops. As a result, both in vitro and in planta methods have been developed to genetically modify tomato (Gerszberg et al. 2015; Shah et al. 2015; Sharada et al. 2017) for tolerance to abiotic and biotic stresses. Abiotic stress factors that limit tomato production and quality include cold, heat, drought and salt with significant recent progress made toward engineering tolerance to these environmental challenges (for e.g., Al-Abdallat et al. 2015; Metwali et al. 2015; Shah et al. 2015). In addition, sustainable production of tomato is limited by biotic stresses caused by pathogens and insects. Genetic transformation has also been used to develop resistance to some of these factors in tomato (reviewed in Gerszberg et al. 2015); however, there are still many diseases and pests that require effective control methods.

Tuta absoluta, tomato leaf miner has been an important pest in South America for many years with yield losses as high as $100 \%$ (Maluf et al. 2010). Tomato leaf miner 
was first reported in Europe (Spain) in 2006 (Urbaneja et al. 2012). Since then, T. absoluta has quickly spread throughout the Mediterranean coastal countries of Europe and Africa (Ponti et al. 2015). Spread is thought to have occurred by agricultural trade (Desneux et al. 2011) despite the fact that $T$. absoluta is a key quarantine pest (EPPO 2005). T. absoluta larvae feed at any stage of plant development and eat apical buds, leaves, stems and fruits thus causing reductions in yield and fruit quality (Desneux et al. 2010). Tomato is the primary host of T. absoluta, however, the insect can also feed on other solanaceous crops including eggplant, potato, pepper and tobacco (Desneux et al. 2010).

Management of $T$. absoluta has primarily relied on chemical control including organophosphate and pyrethroid pesticides (Desneux et al. 2010). Heavy use of pesticides can result in pesticide-resistant strains which have been reported in South America and Europe (Lietti et al. 2005; Roditakis et al. 2015; Silva et al. 2011; Siqueira et al. 2000). Bt pesticide, derived from Bacillus thuringiensis, is an alternative to chemical preparations. Native Bt strains and commercially available preparations have been shown to be highly effective for control of tomato leaf miner with no need for additional pesticide use (González-Cabrera et al. 2010). Moreover, Bt was shown to have no negative effects on a parasitoid of T. absoluta which is used for biological control (Riquelme et al. 2006). Bt-based formulations reduced T. absoluta damage up to $90 \%$; however, they had low persistence on plants and had to be applied weekly (González-Cabrera et al. 2010).

Although several biotechnological approaches to achieving insect resistance in plants have been described, the most widespread and well-tested is the use of cry genes from B. thuringiensis (Ferré et al. 2008). Cry genes encode insecticidal crystal proteins which selectively bind to insect midgut receptors and insert into the gut cell membrane. This causes formation of pores in the membrane and eventual cell lysis and insect death (Knowles and Dow 1993). Different Cry proteins are known to have varying toxicities on different taxa of insects such as Lepidoptera, Coleoptera, Hymenoptera, Diptera and also nematodes (Bravo et al. 2005). Because of the broad spectrum toxic effect of B. thuringiensis Cry proteins, crop plants expressing cry genes have been commercially available since the 1990s and are widely used for control of insect pests in field crops (James 2007). Bt crops have received wide acceptance and now account for more than one-third of all genetically modified crops grown worldwide (Ferré et al. 2008). However, the use of cry genes to control insects has been less popular in vegetable crops than in field crops. Bt tomato lines have also been developed which carry resistance to tomato fruit borer, Colorado potato beetle, and root-knot nematodes (Koul et al. 2014; Kumar and Kumar 2004; Li et al. 2007;
Mandaokar et al. 2000; Saker et al. 2011). However, Bt tomato cultivars are not yet commercially available. To our knowledge, the only reported use of introduced Bt Cry proteins to control T. absoluta was a Bt potato line developed by CIP (International Potato Center). In that work, a line expressing $c r y l A b$ exhibited tolerance to both tuber moth and T. absoluta in field trials (Canedo et al. 1997). Given this report, we hypothesized that transgenic tomato plants expressing a Cry protein gene may exhibit resistance to tomato leaf miner. Thus, we transferred crylAc into tomato cultivar Moneymaker and confirmed the transgenic plants' resistance to $T$. absoluta using both leaf and whole plant bioassays.

\section{Materials and methods}

\section{Vector constructs}

A synthetic crylAc gene was obtained from Dr. I. Altosaar, University of Ottawa, Ontario, Canada (Cheng et al. 1998). The gene construct contained the $c r y l A c$ gene driven by a double CaMV $35 S$ promoter with a nos terminator (Suppl. Fig. 1). The construct was in pRD400, a binary vector that contains a kanamycin selectable marker gene (nptII). This vector was introduced into A. tumefaciens strain LBA4404 via heat shock transformation (Cheng et al. 1998).

\section{Tomato transformation}

Transformation of tomato cv. Moneymaker was carried out as described by Frary and van Eck (2004). Briefly cotyledons of 1 -week old tomato seedling grown in $1 / 2$ MS0 (1/2× MS salts; $100 \mathrm{mg} / \mathrm{L}$ myoinositol, $2 \mathrm{mg} / \mathrm{L}$ thiamine- $\mathrm{HCl}, 0.5 \mathrm{mg} / \mathrm{L}$ pyridoxine- $\mathrm{HCl}, 0.5 \mathrm{mg} / \mathrm{L}$ nicotinic acid, $1 \%$ sucrose, and $0.8 \%$ agar, $\mathrm{pH} 5.8$ ) were cut into two pieces and dipped in a suspension of $A$. tumefaciens transformed with the pRD400 plasmid containing the crylAc gene construct. Cotyledon explants were co-cultivated with A. tumefaciens for $48 \mathrm{~h}$ and then transferred to selective regeneration media for shoot formation $(1 \times$ MS salts, $100 \mathrm{mg} / \mathrm{L}$ myoinositol, $1 \times$ Nitsch vitamins, $2 \%$ sucrose, $0.52 \%$ agargel, $300 \mathrm{mg} / \mathrm{L}$ timentin, $50 \mathrm{mg} / \mathrm{L}$ kanamycin, $2 \mathrm{mg} / \mathrm{L}$ zeatin, $\mathrm{pH}$ 6.0). Selective regeneration medium was renewed every 3 weeks until shoots were large enough to transfer to selective rooting media $(1 \times$ MS salts, $1 \times$ Nitsch vitamins, $3 \%$ sucrose, $0.8 \%$ bacto-agar, $300 \mathrm{mg} / \mathrm{L}$ timentin, $50 \mathrm{mg} / \mathrm{L}$ kanamycin, $\mathrm{pH}$ 6.0). Only one shoot per cotyledon explant was retained to ensure that all candidate transgenic plants represented independent transformation events. After rooting, $\mathrm{T}_{0}$ plantlets were transferred to soil and gradually acclimated to normal atmospheric conditions as described 
in Frary and van Eck (2004). $\mathrm{T}_{0}$ plants were grown and self-pollinated in the greenhouse to produce $\mathrm{T}_{1}$ seeds.

\section{Molecular characterization of $T_{0}$ plants}

Transformation of plants with the cry T-DNA was initially confirmed by PCR analysis on $\mathrm{T}_{0}$ and $\mathrm{T}_{1}$ putative transformants and non-transformed control Moneymaker plants. Genomic DNA was extracted from young leaves of greenhouse-grown plants using a CTAB method (Stewart and Via 1993). Polymerase chain reactions were performed using crylAc specific $1 A c-1$ primers and nptII specific primers. The $25 \mu \mathrm{L}$ PCR reactions contained: $2.5 \mu \mathrm{L} 10 \times$ PCR buffer, $0.2 \mathrm{mM}$ dNTPs, $2 \mathrm{mM} \mathrm{MgCl} 2,100 \mathrm{ng}$ template DNA and $1 \mathrm{U}$ Taq DNA polymerase. The reaction started with incubation for $5 \mathrm{~min}$ at $94^{\circ} \mathrm{C}$ followed by 30 cycles of $60 \mathrm{~s}$ at $94^{\circ} \mathrm{C}, 60 \mathrm{~s}$ at $58^{\circ} \mathrm{C}, 60 \mathrm{~s}$ at $72{ }^{\circ} \mathrm{C}$ and final extension of $5 \mathrm{~min}$ at $72^{\circ} \mathrm{C}$. The amplification products were run on $0.8 \%$ agarose gels. The crylAc plasmid construct was used as positive control in PCR experiments.

Further confirmation of transformation was obtained from Southern hybridization analysis. Genomic DNA was extracted from leaves of approximately 1-month old tomato plants grown in the greenhouse. A total of $25 \mu \mathrm{g}$ genomic DNA from each PCR-verified $\mathrm{T}_{0}$ plant was digested with EcoRI restriction enzyme which cuts once within the T-DNA region (Suppl. Fig. 1). Restriction products were separated in $0.8 \%$ agarose gel. The gels were blotted to positively charged nylon membrane (Roche, Germany) via capillary transfer method. Digoxigenin (DIG) labelled probes were prepared using $c r y l A c$ specific primer $(1 A c-1)$ using the PCR DIG probe synthesis kit (Roche, Germany). Hybridization, wash and immuno-detection were carried out according to the manufacturer's instructions with chromogenic NBT/BCIP (nitroblue tetrazolium/5-bromo4-chloro-3-indolyl-phosphate) used as substrate [DIG High Prime DNA labelling and detection starter kit I (Roche, Germany)].

\section{TAIL-PCR determination of Cry1Ac transgene insertion site}

CrylAc transgene insertion sites in tomato genome were determined using thermal asymmetric interlaced polymerase chain reaction (TAIL-PCR) in four selected transgenic lines $\left(\mathrm{T}_{1}-18, \mathrm{~T}_{1}-20, \mathrm{~T}_{1}-22, \mathrm{~T}_{1}-25\right)$. Five arbitrary primers (ad1, ad2, ad3, ad20 and w4) (Yang et al. 2013) were tested with three Cry1Ac gene-specific sequential nested primers for amplifying the 5' upstream (Cry1Ac51, Cry1Ac52, Cry1Ac53) and 3' downstream regions (Cry1Ac31, Cry1Ac32, Cry1Ac33). A three step sequential PCR method was used for TAIL-PCR. The primary PCR amplification was carried out using $1 \mu \mathrm{g}$ genomic DNA (obtained by CTAB method) as template. The secondary PCR amplification was performed using a 10 -fold dilution of primary PCR product. The product of this amplification was diluted in the same way and used for tertiary PCR amplification. The PCR mixture and the amplification conditions were in accordance with Pillai et al. (2008). The two largest bands produced by tertiary TAIL PCR for both $5^{\prime}$ upstream and $3^{\prime}$ downstream regions were extracted from agarose gel and cloned into TA cloning vector (pTZ57R/T, Thermo Scientific) and subsequently sequenced for four tested transgenic lines. The sequence analyses for the CrylAc gene 5' and 3' proximal regions were performed via blast analysis against the tomato genome database (https://solgenomics.net/tools/ blast/).

\section{Expression analyses}

mRNA expression levels of the crylAc gene were determined by RT-qPCR experiments. Primers specific to crylAc were designed (lAc-2, Suppl. Table 1) using Primer3 software (Rozen and Skaletsky 1999). The cac gene (clathrin adaptor complex medium subunit/endocytic pathway gene) was selected as the reference gene (primers given in Suppl. Table 1) as it was shown to be stably expressed in tomato leaf tissues (Expósito-Rodríguez et al. 2008). Total RNA was extracted from $T_{1}$ plants from four independent transgenic $\mathrm{T}_{0}$ plants using the RNeasy plant mini kit (Qiagen, Germany) according to the manufacturer's instructions. RNA samples were treated with DNase (NEB, UK) and total RNA concentration was quantified using Nanodrop Spectrophotometer (MultiskanGO Microplate Spectrophotometer, Thermo Scientific, USA). Total RNA $(1 \mu \mathrm{g})$ was used for cDNA synthesis via Transcriptor First Strand cDNA Synthesis Kit (Roche, Germany) using anchored oligo $(\mathrm{dT})_{18}$ primers, according to the manufacturer's instructions. RT-qPCR reactions were performed using LightCycler 480 SYBR Green master mix (Roche, Germany) according to the manufacturer's instructions with 1:10 diluted cDNA samples as template. PCR reactions $(10 \mu \mathrm{l})$ were performed with a LightCycler 480 (Roche, Germany) with a program containing pre-incubation, amplification, melting curve and cooling steps according to the manufacturer's instructions. Experiments were carried out with three biological and two technical replicates for each sample and relative expression levels were calculated using the $2^{-\Delta \mathrm{Ct}}$ method (Livak and Schmittgen 2001). The $\Delta \mathrm{Ct}$ value in the formula was calculated by subtracting the $\mathrm{Ct}$ value of the target gene crylAc from the $\mathrm{Ct}$ value of the reference gene, $c a c$. Relative expression levels were calculated as fold change proportional to the $T_{1}$ individual having the lowest expression level $\left(\mathrm{T}_{1}-20-5\right.$, a progeny of $\mathrm{T}_{0}-20$ ). 
Immunodetection of total protein extracts was carried out with the leaves of approximately 1-month old greenhouse grown plants using $50 \mathrm{mM} \mathrm{MES} / \mathrm{KOH}$ buffer (40 mM KCl, $2 \mathrm{mM} \mathrm{CaCl}_{2}, 0.02 \mathrm{M} \mathrm{PMSF}$, pH 6). After protein extraction, total protein concentration was determined according to Bradford protein assay (Bradford 1976). Total protein $(100 \mu \mathrm{g})$ from each sample was boiled for 5 min with $2 \times$ sample loading dye $(50 \mathrm{mM}$ Tris $-\mathrm{HCl}$ pH 6.8, $100 \mathrm{mM}$ DTT, 2\% SDS, 0.1\% bromophenol blue, $10 \%$ glycerol) and loaded on a $12 \%$ SDS-PAGE gel. Separated proteins were blotted to $0.2 \mathrm{~mm}$ pore size immunoblot PVDF membrane (Bio-Rad, USA) using a Mini TransblotCell (Bio-Rad, USA) at $30 \mathrm{~V}$ overnight in transfer buffer (25 mM Tris base, $192 \mathrm{mM}$ glycine, 0.1\% SDS). Blotted membrane was blocked with TBST buffer $(137 \mathrm{mM}$ $\mathrm{NaCl}, 2.7 \mathrm{mM} \mathrm{KCl}, 19 \mathrm{mM}$ Tris base, 0.1\% Tween-20, $\mathrm{pH}$ 7.4) containing $10 \%$ fat-free milk protein. After blocking, the membrane was incubated with primary antibody (AntiBacillus thuringiensis CRY1Ab toxin antibody ab51586, Abcam, USA) diluted 1:2500 in TBST buffer with 5\% fatfree milk protein. The membrane was washed with TBST buffer three times and incubated with a 1:10,000 dilution of secondary antibody (Anti-rabbit IgG, HRP-linked Antibody 7074, Cell Signalling Technology, UK). Finally, the Luminata Crescendo Western HRP substrate (Millipore, USA) was added and the membrane was visualized in a Biorad Versa DOC (Bio-Rad, USA) chemiluminescence detection system.

\section{Insect bioassays}

Both detached leaf and whole plant insect bioassays were conducted using four genotypes. T. absoluta larvae were fed on Moneymaker tomato leaves for approximately 30 days until adult $T$. absoluta were obtained. Adult moths were then placed in insect cages with tomato plants and damp cotton pads to provide egg laying surfaces. Transgenic tomato plants were grown for approximately 1 month in the greenhouse. Detached leaves were placed in petri dishes containing $1.5 \%$ agar which helped the leaves to preserve their freshness for 10 days. For each genotype, 2-3 leaves were used for each test and 20 T. absoluta eggs (4-5 days old) were placed on each leaf using a soft brush. After transfer of the eggs, the petri dishes were covered with stretch film and 20-30 holes were made in the film to provide ventilation for the eggs. Larvae emerged from eggs 1 or 2 days after transfer. The number of living larvae was recorded after 8-10 days. Larvae growth and feeding characters were investigated for each tomato genotype under a stereo microscope.

For whole plant assays, 4-5 day-old T. absoluta eggs (30) were transferred to three or four leaves of tomato plants that were 1 month old. 8-10 days after larvae emergence, the number of the living larvae was counted and the growth and feeding habits of the larvae were investigated as in the detached leaf bioassay.

Correlation analyses were carried out between relative crylAc gene mRNA expression levels and observed traits in leaf bioassays using $\mathrm{R}$ software Hmics package with Kendall rank correlation method.

\section{Results}

\section{Development of transgenic tomato lines and confirmation of $c r y 1 A c$ integration}

Agrobacterium tumefaciens strain LBA 4404 transformed with pRD400 plasmid containing the crylAc gene in its T-DNA (Suppl. Fig. 1) was transformed into tomato cotyledon explants. The Moneymaker cultivar was used in transformation studies and 25 independent candidate transgenic plants were regenerated. Of these $25 \mathrm{~T}_{0}$ plants, 12 were verified to contain the crylAc gene via PCR amplification using crylAc specific primers (1Ac-1) (Suppl. Fig. 2). Southern blot analysis was carried out on the $12 \mathrm{~T}_{0}$ plants for verification of transgene integration and determination of copy number. EcoRI was used for DNA digestion as it cuts the T-DNA once (Suppl. Fig. 1). Southern hybridization with $c r y l A c$ gene specific DNA probes indicated that three plants contained single copies of the transgene $\left(\mathrm{T}_{0}-19, \mathrm{~T}_{0}-20, \mathrm{~T}_{0}-26\right)$ while the remaining nine contained two copies (data not shown).

Four of the transgenic $\mathrm{T}_{0}$ plants were selected for further experiments based on gene copy number. One of the plants $\left(\mathrm{T}_{0}-20\right)$ had a single insertion while the other plants had two insertions $\left(\mathrm{T}_{0}-18, \mathrm{~T}_{0}-22, \mathrm{~T}_{0}-25\right)$. These $\mathrm{T}_{0}$ plants were self-pollinated to generate $\mathrm{T}_{1}$ seeds which were germinated in $1 / 2$ MS0 medium containing $50 \mathrm{mg} / \mathrm{L}$ kanamycin and transferred into soil 3 weeks after germination. DNA was extracted from the kanamycin resistant $\mathrm{T}_{1}$ plants and PCR amplifications were carried out using crylAc (1Ac-1 and $1 A c-2$ ) and nptII gene specific (nptII) primers. All of the $\mathrm{T}_{1}$ seeds that germinated on selective medium were confirmed to be transgenic. Southern analysis also confirmed stable transmission of the T-DNA to the $\mathrm{T}_{1}$ generation (data not shown).

The locations of the CrylAc transgene integrations in the tomato genome were identified in the four selected transgenic lines $\left(\mathrm{T}_{1}-18, \mathrm{~T}_{1}-20, \mathrm{~T}_{1}-22, \mathrm{~T}_{1}-25\right)$ using TAILPCR for determination of the $5^{\prime}$ and $3^{\prime}$ flanking regions. Three step sequential nested PCR was carried out and the two longest fragments of the tertiary TAIL-PCR reaction were cloned and sequenced. The resulting DNA sequences were searched against the tomato genome and MIPS tomato repeat collection databases using Blast (https:// 
solgenomics.net/tools/blast/). The MIPS database includes repetitive elements such as transposons, micro- and minisatellites as well as high copy number genes like histones (Spannagl et al. 2007). For transgenic line $\mathrm{T}_{1}-20$, the isolated TAIL PCR fragments mapped to tomato chromosome 4 (99\% match of $997 \mathrm{bp}$ fragment) (Suppl. Table 2), confirming the single copy results observed in Southern blot analysis. For transgenic line $\mathrm{T}_{1}-22$, the isolated TAIL-PCR fragments mapped to tomato chromosomes 5 (99\% match of a $317 \mathrm{bp}$ fragment) and 6 (99\% match of $1068 \mathrm{bp})$. Thus, the results indicate insertion of two copies of the transgene, consistent with Southern blot analysis. For transgenic line $\mathrm{T}_{1}$-18 there was no match against tomato chromosomes, however, the isolated fragments matched the MIPS tomato repeat library, with a match to k_29 (mips:kail02.01.02.10 SINElrptmsk SINEltigr TERT04) (97\% match to a $133 \mathrm{bp}$ fragment) and camv (IWaksmanl02.01 Retroelementlrptmsk -Itigr TERT) (93\% match of a $312 \mathrm{bp}$ fragment) (Suppl. Table 2). The fact that two matches were found is consistent with Southern blot analysis which indicated that two copies were inserted in the tomato genome. TAIL-PCR fragments for transgenic line $T_{1}-18$ also matched the MIPS tomato repeat library, with a match to k_29 (mips:kail02.01.02.10 SINElrptmsk SINEltigr TERT04) (97\% match to a $133 \mathrm{bp}$ fragment) and camv (IWaksman|02.01 Retroelementlrptmsk -Itigr TERT) (96\% match of a 334 bp fragment), thus, confirming that this plant contained two copies of the transgene.

\section{Expression of $\operatorname{cry} 1 A c$ at the mRNA and protein levels}

RT-qPCR experiments were performed for analysis of mRNA expression levels in transgenic $T_{1}$ plants from the four independent $\mathrm{T}_{0}$ plants described above. As expected, non-transgenic Moneymaker tomato plants did not show crylAc transcription. $\mathrm{T}_{1}$ progenies of $\mathrm{T}_{0}-20$ had the lowest crylAc transcript levels. The expression level of the lowest crylAc expressing individual $\left(\mathrm{T}_{1}-20-5\right)$ was set as the standard (given a value of 1) and the expression levels of the other plants were compared to this individual (Fig. 1). $\mathrm{T}_{1}$ progenies of $\mathrm{T}_{0}-25$ had the highest crylAc expression in leaf tissue with expression levels 160 - to 750 -fold higher than those of the standard. The $T_{1}$ progenies of $T_{0}-18$ had expression levels between 160- and 200-fold the standard while $\mathrm{T}_{0}$-22 progenies' mRNA expression levels were between 27- and 120-fold. Thus, the expression level of the transgene in the plant with single copy insertion $\left(\mathrm{T}_{0}-20\right)$ was significantly lower than the plants with two copies in their genomes In order to verify that transgenic plants were expressing Bt crystal protein, Western blot analysis was carried out on selected $\mathrm{T}_{1}$ plants. Thus, the $\mathrm{T}_{1}$ progenies of the transgenic plants with CrylAc expression were found to contain the Cry1Ac protein (Suppl. Fig. 3).

\section{Bioassays for T. absoluta tolerance}

$\mathrm{T}_{1}$ plants from the four independent $\mathrm{T}_{0}$ plants were subjected to T. absoluta bioassay using two methods. In the first method, 20 eggs were placed on leaves of control and transgenic $\mathrm{T}_{1}$ plants in petri dishes (Fig. 2a). Larvae feeding and vigor were evaluated 8-10 days after hatching. Non-transgenic Moneymaker leaves were full of galleries made by $T$. absoluta larvae and all the larvae were wellfed (Fig. 2b). In contrast, larvae did much less feeding on leaf mesophyll tissue of transgenic $\mathrm{T}_{1}$ plants. In most of the transgenic plants, in particular the progenies of $\mathrm{T}_{0}-22$,
Fig. 1 Detection of CrylAc gene expression with RT-qPCR in $26 \mathrm{~T}_{1}$ transgenic seedlings resulting from self-pollination of four $\mathrm{T}_{0}$ lines. Results are shown as the relative expression levels normalized to the lowest CrylAc expressing $\mathrm{T}_{1}$ plant $\left(\mathrm{T}_{1}-20-5\right)$ which was set as 1 . Data are given as means $\pm \mathrm{SE}$ of two technical replicates per plant

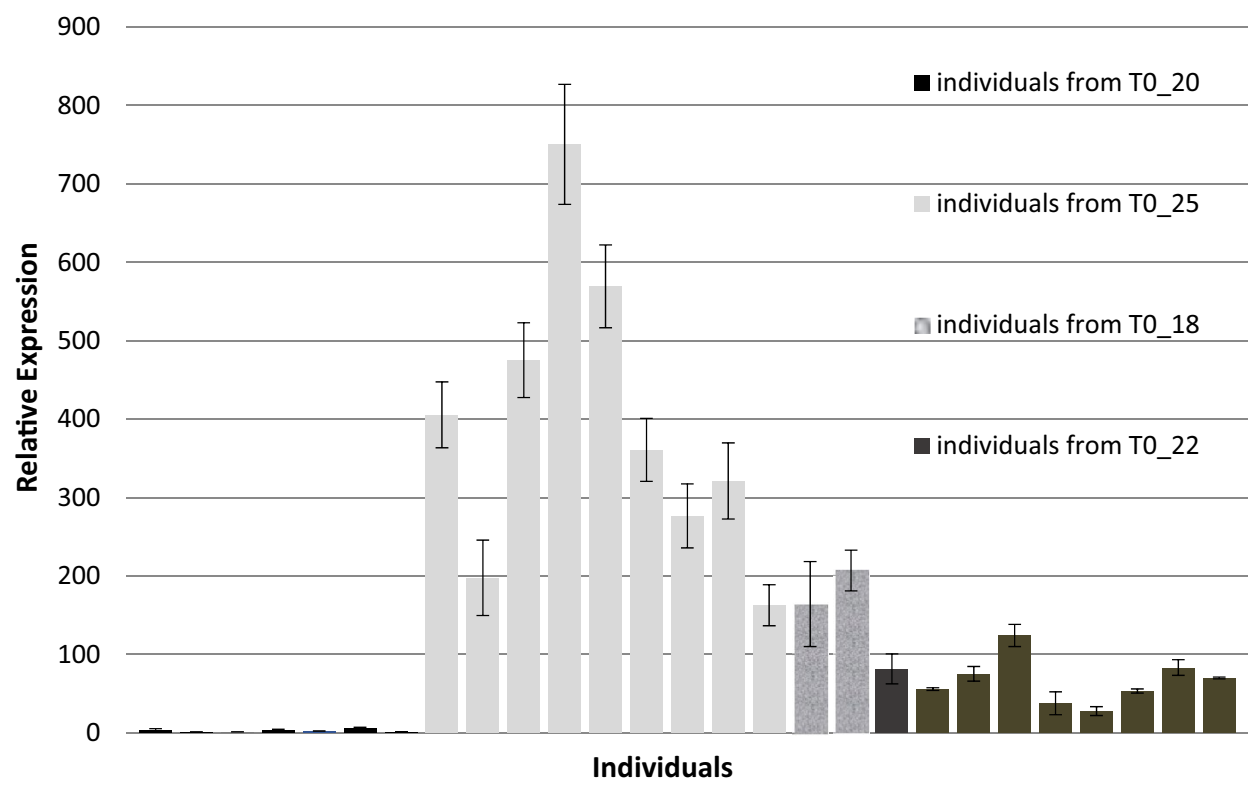



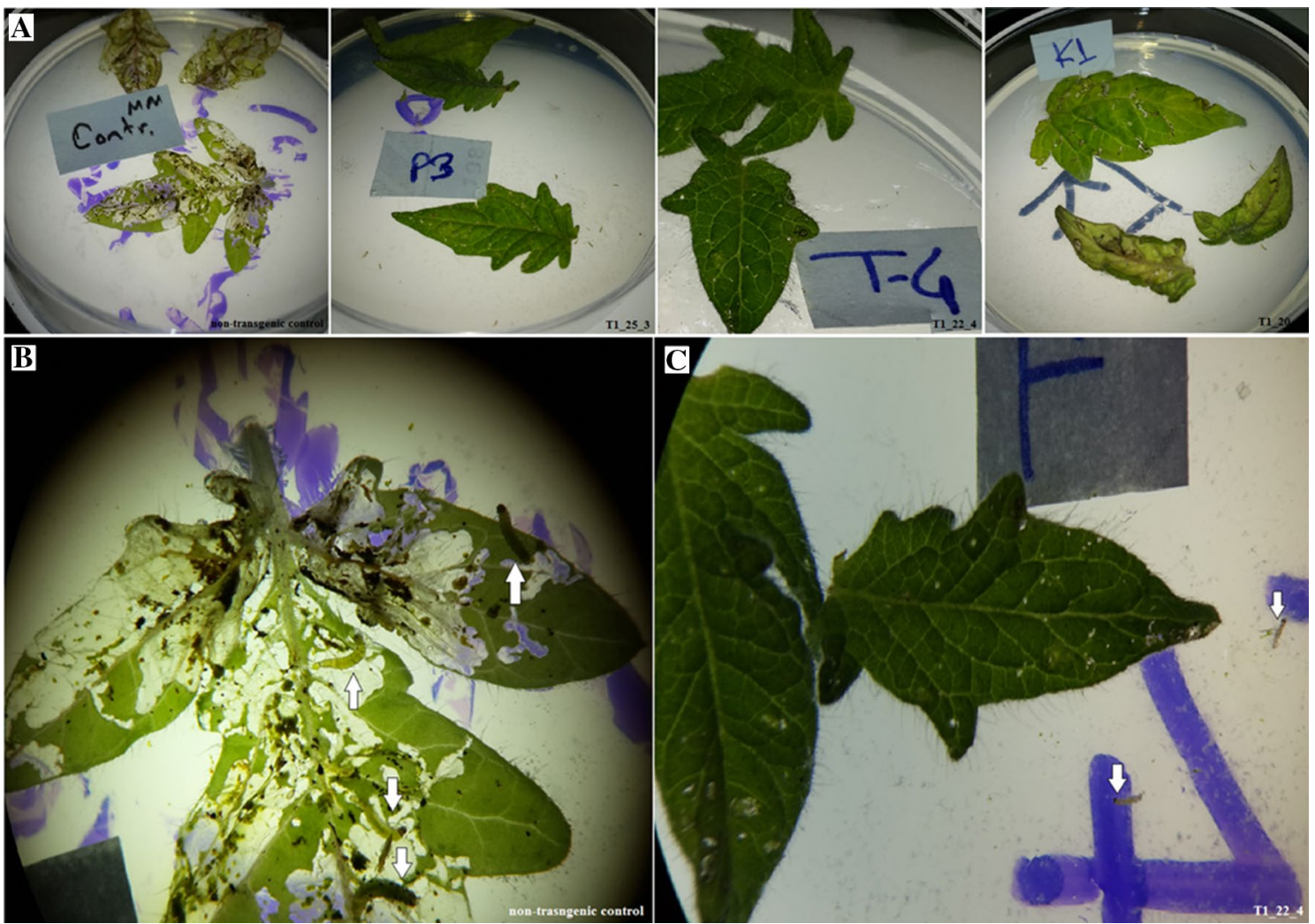

Fig. 2 Insect bioassays with T. absoluta in non-transgenic Moneymaker plants and transgenic $\mathrm{T}_{1}$ plants from three different $\mathrm{T}_{0}$ transgenic lines. Photos were taken 8 days after larvae hatched. a Nontransgenic and transgenic tomato leaves explants artificially infested with T. absoluta eggs in petri dishes. b Well-fed, vigorous larvae (arrows) feeding on non-transgenic Moneymaker plant. c Underdeveloped, dead larvae (arrows) after feeding on transgenic $\mathrm{T}_{1}$ plant leaves

CrylAc mRNA expression $(\mathrm{r}=0.5, \mathrm{p}=0.005$, Kendall rank correlation test). Surviving larvae were scored in terms of health, size and mobility from 3 (largest and most mobile larvae) to 0 (no surviving larvae) and the frequencies of the highly observed scores were calculated. The surviving larvae were smaller and less mobile on transgenic lines
Table 1 Detached leaf bioassay via artificial infestation of nontransgenic control Moneymaker and transgenic $\mathrm{T}_{1}$ tomato leaf explants with $T$. absoluta larvae

\begin{tabular}{llclll}
\hline Name of individual & $\begin{array}{l}\text { No. of } \\
\text { gene copy }\end{array}$ & Mortality rate $\%^{\mathrm{a}}$ & Bite scars $^{\mathrm{b}}$ & Gallery formation $^{\mathrm{c}}$ & Larvae vigor $^{\mathrm{d}}$ \\
\hline Moneymaker & 0 & $0(12.7 \pm 0.3)$ & $5(100 \%)$ & $3(100 \%)$ & $3(100 \%)$ \\
$\mathrm{T} 1-20$ & 1 & $38(3.7 \pm 2.1)$ & $3(71 \%)$ & $2(57 \%)$ & $3(57 \%)$ \\
$\mathrm{T} 1-25$ & 2 & $95(0.7 \pm 0.4)$ & $1(67 \%)$ & $0(89 \%)$ & $0(78 \%)$ \\
$\mathrm{T} 1-18$ & 2 & $67(4 \pm 1.0)$ & $2(50 \%)$ & $1(100 \%)$ & $0(100 \%)$ \\
$\mathrm{T} 1-22$ & 2 & $100(0 \pm 0)$ & $1(90 \%)$ & $0(90 \%)$ & $0(100 \%)$ \\
\hline
\end{tabular}

${ }^{a}$ Viability and mortality of insects were recorded at 8 days after larvae emergence. Number of living larvae $\pm \mathrm{SE}$ is given in parenthesis

${ }^{b}$ Bite scars caused by feeding of larvae were scored up to 5 for the most scars and 1 for the least scars. Frequencies of the most common group are given in parenthesis

${ }^{c}$ Gallery formation caused by larvae feeding in the leaves was scored up to 3 for the most and widest galleries and 0 for no gallery formation. Frequencies of the most common groups are given in parenthesis

${ }^{\mathrm{d}}$ Larvae vigor was scored as 3 for the best grown, most mobile larvae and 0 for larvae that were dead by the end of the experiment. Frequencies of the most common group are given in parenthesis 
compared to those fed on non-transgenic control leaves. The non-transgenic plants had the largest and most mobile larvae with a score of 3 for $100 \%$ of the tested plants. The scores for the transgenic plants were most often 0 with only line $\mathrm{T}_{1}$-20 having a score of 3 indicating feeding similar to the non-transgenic control (Table 1). Gallery formation and bite scars were inversely correlated with CrylAc mRNA expression $(\mathrm{r}=-0.58, \mathrm{p}=0.005$ and $\mathrm{r}=-0.54, \mathrm{p}=0.007$, respectively, Kendall rank correlation test).

Similar results were obtained from whole plant tests. For these experiments, $30 \mathrm{~T}$. absoluta eggs were placed on leaves of the tomato plants and damage caused by feeding and larvae vigor was monitored 8-10 days after larvae emerged. Leaves of the non-transgenic Moneymaker tomato plants were heavily damaged by feeding of the larvae. However, little damage was caused by larvae feeding in transgenic plants with small scars or only a few, small galleries observed in different transgenic individuals. Average number of the surviving larvae varied from 1.1 to 6 in transgenic lines and was 15 for non-transgenic controls (Table 2). Larvae vigor was scored as described for detached leaf tests. The non-transgenic plants had the largest and most mobile larvae whereas the transgenic plants showed limited feeding (Table 2).

\section{Discussion}

Bt cry genes are widely used in crop genetic engineering and the resulting plants, including cotton and maize, comprise a huge portion of total transgenic crop production (Sanahuja et al. 2011). Bt crops are used for eco-friendly control of insect pests on plants and have been reported to be safe to vertebrates and natural enemies of insect pests (Ferré et al. 2008). T. absoluta is a major insect pest of tomato limiting the yield and quality of tomato production in both open fields and greenhouses especially in South America and the Mediterranean. Control of T. absoluta based on chemical sprays is costly and can be harmful to the environment and human health. Moreover, such measures are ineffective for $T$. absoluta because its larvae feed within the galleries they form in the mesophyll tissue of leaves (Desneux et al. 2010). The insect can be controlled with commercial $\mathrm{Bt}$ formulations containing different strains of $B$. thuringiensis (ex: Dipe ${ }^{\circledR} B$. thuringiensis kurstaki strain expressing Cry1Aa, Cry1 Ab, Cry1Ac, Cry2Aa, Cry2Ab proteins, Valent Bioscience). However, control requires frequent spraying and is not consistent (González-Cabrera et al. 2010). In previous studies, cry genes were over-expressed in tomato plants and were identified to confer tolerance to several different insect pests including Helicoverpa armigera, Heliothis zea, Spodoptera litura, and Manduca sexta (Delannay et al. 1989; Fischhoff et al. 1987; Koul et al. 2014; Kumar and Kumar 2004; Mandaokar et al. 2000; Saker et al. 2011). However, these plants were not tested for their resistance to T. absoluta. Thus, our study is the first report of the development of transgenic tomato lines specifically for resistance to $T$. absoluta.

The transgenic tomato plants over-expressing the CrylAc gene were evaluated for their resistance to $T$. absoluta via artificial infestation of detached leaves and whole plants with $T$. absoluta larvae. The damage caused by $T$. absoluta feeding in leaf tissues of transgenic plants carrying one or two copies of the transgene was significantly reduced. Gallery formation in leaves caused by larvae feeding was restricted compared to the non-transgenic individuals, in which the leaf tissue was almost completely consumed by the larvae. Damage was limited to small scars in the leaves of the transgenic plants which were caused by the initial feeding attempts of the larvae. Moreover, the viability of the larvae was low in
Table 2 Whole plant bioassay via artificial infestation of nontransgenic control Moneymaker and transgenic $\mathrm{T}_{1}$ plants with $T$. absoluta larvae

\begin{tabular}{llllll}
\hline Name of individual & $\begin{array}{l}\text { No. of } \\
\text { gene copy }\end{array}$ & No. of alive & Bite scars & Gallery formation & \\
\hline Moneymaker & 0 & 15 & 3 & 3 & Larvae vigor $^{\mathrm{b}}$ \\
T1-20 & 1 & $4.4 \pm 1.3$ & $3(80 \%)$ & $2(80 \%)$ & $2(60 \%)$ \\
T1-25 & 2 & $1.8 \pm 0.5$ & $1(50 \%)$ & $0(50 \%)$ & $1(40 \%)$ \\
T1-18 & 2 & $6 \pm 1.0$ & $2(100 \%)$ & $2(100 \%)$ & $1(50 \%)$ \\
T1-22 & 2 & $1.1 \pm 0.3$ & $1(80 \%)$ & $1(80 \%)$ & $0(50 \%)$ \\
\hline
\end{tabular}

${ }^{a}$ Viability and mortality of insects were scored at 8 days after the hatch of larvae. Number of living lar$\mathrm{vae} \pm \mathrm{SE}$ is given

${ }^{b}$ Bite scars caused by feeding of larvae were scored up to 5 for the most scars and 1 for the least scars. Frequencies of the most common group are given in parenthesis

${ }^{\mathrm{c}}$ Gallery formation caused by larvae feeding in the leaves was scored up to 3 for the most and widest galleries and 0 for no gallery formation. Frequencies of the most common groups are given in parenthesis

${ }^{\mathrm{d}}$ Larvae vigor was scored as 3 for the best grown, most mobile larvae and 0 for larvae that were dead by the end of the experiment. Frequencies of the most common group are given in parenthesis 
transgenic plants. In addition, the surviving larvae were smaller and less mobile compared to those fed on nontransgenic Moneymaker plants. Thus, there was a clear difference in the T. absoluta resistance of non-transgenic Moneymaker and transgenic plants.

Variability was seen in the degree of tolerance of different $\mathrm{T}_{1}$ lines. We observed significant differences directly related to copy number which could also be due to insertion site effects. The variability in tolerance was associated with the observed differences in mRNA expression levels of the lines. We also mapped the transgene insertion sites in the tomato genome with TAIL-PCR and we identified the chromosomal locations of the transgenes in two of the transgenic lines. The other two transgenic plants were found to have insertions in transposable elements in the tomato genome and, thus, could not be mapped to specific locations. The three transgenic lines with the highest crylAc mRNA expression had two copies of the transgene and had the least damage caused by larvae feeding. These plants also had fewer surviving larvae compared to the low expressing line with a single copy of the transgene. Thus, we observed a significant correlation between relative mRNA expression of the crylAc gene and larvae mortality rate. There were also inverse correlations between relative mRNA expression of the $c r y l A c$ gene and both gallery formation and bite scars. Because $\mathrm{T}_{1}$ transgenic lines were used, we analyzed a mixed population of hemizygous and homozygous individuals. Despite the differences in gene copy number and zygosity, we observed similar degrees of tolerance within the lines which indicates that a single copy of the gene in the hemizygous condition is sufficient to confer tolerance to this pest.

In conclusion, we developed transgenic tomato plants over-expressing the crylAc gene and confirmed that these lines are resistant to T. absoluta, one of the most damaging insect pests of tomato. The transgenic lines developed in this work can be used in breeding programs for the introgression of insect resistance into commercially important tomato standard and hybrid varieties. The lines should also be tested for their resistance to other important tomato pests for which the Bt toxin is effective.

Acknowledgements We thank Dr. I. Altosaar, University of Ottawa, Canada for the cry gene construct. This work was supported by a grant from Izmir Institute of Technology (2014-IYTE-32).

Author contributions HS transformed plants, performed molecular analyses and drafted paper with AF; FD and NM designed and performed insect bioassays; $\mathrm{SD}$ and $\mathrm{AF}$ devised and oversaw experimental work.

\section{References}

Al-Abdallat AM, Ali-Sheikh-Omar MA, Alnemer LM (2015) Overexpression of two ATNAC3-related genes improves drought and salt tolerance in tomato (Solanum lycopersicum L.). Plant Cell Tissue Organ Cult 120:989-1001

Bradford MM (1976) A rapid and sensitive method for the quantitation of microgram quantities of protein utilizing the principle of protein-dye binding. Anal Chem 72:248-254

Bravo A, Gill S, Soberón M (2005) Bacillus thuringiensis mechanisms and use. In: Gilbert LL, Iatrou K, Gill SS (eds) Comprehensive molecular insect science, 6th edn. Elsevier, Amsterdam, pp 175-205

Canedo V, Benavides J, Golmirzaie A, Cisneros F, Ghislain M, Lagnaoui A (1997) Assessing Bt-transformed potatoes for potato tuber moth, Phthorimaea operculella (Zeller), management. Program Rep 98:161-170

Cheng X, Sardana R, Kaplan H, Altosaar I (1998) Agrobacteriumtransformed rice plants expressing synthetic cryIA (b) and cryIA (c) genes are highly toxic to striped stem borer and yellow stem borer. Proc Natl Acad Sci USA 95:2767-2772

Delannay X, LaVallee BJ, Proksch RK, Fuchs RL, Sims SR, Greenplate JT, Marrone PG, Dodson RB, Augustine JJ, Layton JG, Fischhoff DA (1989) Field performance of transgenic tomato plants expressing the Bacillus thuringiensis var. kurstaki insect control protein. Nat Biotechnol 7:1265-1269

Desneux N, Wajnberg E, Wyckhuys KA, Burgio G, Arpaia S, Narváez-Vasquez CA, González-Cabrera J, Ruescas DC, Tabone E, Frandon J, Pizzol J (2010) Biological invasion of European tomato crops by Tuta absoluta: ecology, geographic expansion and prospects for biological control. J Pest Sci 83:197-215

Desneux N, Luna MG, Guillemaud T, Urbaneja A (2011) The invasive South American tomato pinworm, Tuta absoluta, continues to spread in Afro-Eurasia and beyond: the new threat to tomato world production. J Pest Sci 84:403-408

EPPO (European and Mediterranean Plant Protection Organization) (2005) EPPO reporting service. http://archives.eppo.int/ EPPOReporting/2005/Rse-0509.pdf. Accessed 15 Sept 2015

Expósito-Rodríguez M, Borges AA, Borges-Pérez A, Pérez JA (2008) Selection of internal control genes for quantitative real-time RTPCR studies during tomato development process. BMC Plant Biol 8:131

Ferré J, Van Rie J, MacIntosh SC (2008) Insecticidal genetically modified crops and insect resistance management (IRM). In: Romeis J, Shelton AM, Kennedy GG (eds) Integration of insect-resistant genetically modified crops within IPM programs, 5th ed. Springer, Dordrecht, pp 41-85

Fischhoff DA, Bowdishi KS, Perlak FJ, Marrone PG, McCormick SM, Niedermeyer JG, Dean DA, Kusano-Kretzmer K, Mayer EJ, Rochester DE, Rogers SG (1987) Insect tolerant transgenic tomato plants. Nat Biotechnol 5:807-813

Frary A, Van Eck J (2004) Organogenesis from transformed tomato explants. In: Pena L (ed) Transgenic plants: methods and protocols. Springer, Dordrecht, pp 141-150

Gerszberg A, Hnatuszko-Konka K, Kowalczyk T, Kononowicz AK (2015) Tomato (Solanum lycopersicum L.) in the service of biotechnology. Plant Cell Tissue Organ Cult 120:881-902

González-Cabrera J, Mollá O, Montón H, Urbaneja A (2010) Efficacy of Bacillus thuringiensis (Berliner) in controlling the tomato borer, Tuta absoluta (Meyrick) (Lepidoptera: Gelechiidae). Biocontrol 56:71-80

James C (2007) Global status of commercialized biotech/GM crops, 2007, vol 37. ISAAA Ithaca, New York

K1lıç T (2010) First record of Tuta absoluta in Turkey. Phytoparasitica 38:243-244 
Knowles BH, Dow JA (1993) The crystald-endotoxins of Bacillus thuringiensis: models for their mechanism of action on the insect gut. Bioessays 15:469-476

Koul B, Srivastava S, Sanyal I, Tripathi B, Sharma V, Amla DV (2014) Transgenic tomato line expressing modified Bacillus thuringiensis cry1 Ab gene showing complete resistance to two lepidopteran pests. Springerplus 3:84-96

Kumar H, Kumar V (2004) Tomato expressing Cry1A(b) insecticidal protein from Bacillus thuringiensis protected against tomato fruit borer, Helicoverpa armigera (Hübner) (Lepidoptera: Noctuidae) damage in the laboratory, greenhouse and field. Crop Prot 23:135-139

Li XQ, Wei JZ, Tan A, Aroian RV (2007) Resistance to root-knot nematode in tomato roots expressing a nematicidal Bacillus thuringiensis crystal protein. Plant Biotechnol J 5:455-464

Lietti MMM, Botto E, Alzogaray RA (2005) Insecticide resistance in Argentine populations of Tuta absoluta (Meyrick) (Lepidoptera: Gelechiidae). Neotrop Entomol 34:113-119

Livak KJ, Schmittgen TD (2001) Analysis of relative gene expression data using real-time quantitative PCR and the $2-\Delta \Delta C T$ method. Methods 25:402-408

Maluf WR, Silva VD, Cardoso MD, Gomes LAA, Neto ACG, Maciel GM, Nizio DAC (2010) Resistance to the South American tomato pinworm Tuta absoluta in high acylsugar and/or high zingiberene tomato genotypes. Euphytica 176:113-123

Mandaokar A et al (2000) Transgenic tomato plants resistant to fruit borer (Helicoverpa armigera Hubner). Crop Prot 19:307-312

Metwali EM, Soliman HI, Fuller MP, Almaghrabi OA (2015) Improving fruit quality in tomato (Lycopersicum esculentum Mill) under heat stress by silencing the vis 1 gene using small interfering RNA technology. Plant Cell Tissue Organ Cult 121:153-166

Pillai MM, Venkataraman GM, Kosak S, Torok-Storb B (2008) Integration site analysis in transgenic mice by thermal asymmetric interlaced (TAIL)-PCR: segregating multiple-integrant founder lines and determining zygosity. Transgenic Res 17:749-754

Ponti L, Gutierrez AP, Altieri MA (2015) Holistic approach in invasive species research: the case of the tomato leaf miner in the Mediterranean Basin. Agroecol and Sust Food 39:436-468

Riquelme V, Botto E, Lafalce C (2006) Efficacy of insecticides against the "tomato moth", Tuta absoluta (Lepidoptera: Gelechiidae) and their residual effects on the parasitoid Trichogrammatoidea bactrae (Hymenoptera: Trichogrammatidae). Rev Soc Entomol Argent 65(3-4):57-65

Roditakis E, Vasakis E, Grispou M, Stavrakaki M, Nauen R, Gravouil M, Bassi A (2015) First report of Tuta absoluta resistance to diamide insecticides. J Pest Sci 88:9-16
Rozen S, Skaletsky H (1999) Primer3 on the WWW for general users and for biologist programmers. In: Misener S, Krawetz S (eds) Bioinformatics methods and protocols. Springer, Dordrecht, pp 365-386

Saker MM, Salama HS, Salama M, El-Banna A, Abdel Ghany NM (2011) Production of transgenic tomato plants expressing Cry $2 \mathrm{Ab}$ gene for the control of some lepidopterous insects endemic in Egypt. J Genet Eng Biotechnol 9:149-155

Sanahuja G, Banakar R, Twyman RM, Capell T, Christou P (2011) Bacillus thuringiensis: a century of research, development and commercial applications. Plant Biotechnol J 9:283-300

Shah SH, Ali S, Jan SA, Ali GM (2015) Piercing and incubation method of in planta transformation producing stable transgenic plants by overexpressing DREB1A gene in tomato (Solanum lycopersicum Mill.). Plant Cell Tissue Organ Cult 120:1139-1157

Sharada MS, Kumari A, Pandey AK, Sharma S, Sharma P, Sreelakshmi Y, Sharma R (2017) Generation of genetically stable transformants by Agrobacterium using tomato floral buds. Plant Cell Tissue Organ Cult 129:299-312

Silva GA, Picanco MC, Bacci L, Crespo AL, Rosado JF, Guedes RN (2011) Control failure likelihood and spatial dependence of insecticide resistance in the tomato pinworm, Tuta absoluta. Pest Manag Sci 67:913-920

Siqueira HÁA, Guedes RNC, Picanço MC (2000) Insecticide resistance in populations of Tuta absoluta (Lepidoptera: Gelechiidae). Agric For Entomol 2:147-153

Spannagl M, Noubibou O, Haase D, Yang L, Gundlach H, Hindemitt T, Klee K, Haberer G, Schoof H, Mayer KF (2007) MIPSPlantsDB - plant database resource for integrative and comparative plant genome research. Nucleic Acids Res 35(suppl 1):D834-D840

Stewart CN Jr, Via LE (1993) A rapid CTAB DNA isolation technique useful for RAPD fingerprinting and other PCR applications. Biotechniques 14:748-750

Urbaneja A, Gonzalez-Cabrera J, Arno J, Gabarra R (2012) Prospects for the biological control of Tuta absoluta in tomatoes of the Mediterranean basin. Pest Manag Sci 68:1215-1222

Yang C, Zhang D, Yang L (2013) Development of event-specific PCR detection methods for genetically modified tomato Huafan No. 1. J Sci Food Agric 93:652-660 